"At no time shall said premises or any part thereof or any building erected thereon be sold, occupied, let or leased or given to any one of any race other than the Caucasian, except that this covenant shall not prevent occupancy by domestic servants of a different race domiciled with an owner or tenant." 1 This deed restriction is typical of thousands which are still part of property records in the United States despite the fact that none can now be honored by either a federal or a state court. In 1948, in four cases where neighbors sought to enjoin sale to and occupancy by nonCaucasians, the Supreme Court ruled that such covenants are not enforceable, and in 1953 the Supreme Court emphasized this ruling by holding that money damages could not be collected from a seller who violated a covenant. These decisions allow Negroes to rent or purchase property without the hindrance of such restrictive covenants. In effect, the Court withdrew governmental sanction for the established pattern of racial segregation in Northern cities. This book attempts to describe the sociological and political events leading to these decisions in the Restrictive Covenant Cases ${ }^{2}$ and to appraise the practical result of the Supreme Court's rulings.

A number of contrasts follow the fact that the Restrictive Covenant Cases of 1948 and 1953 ended judicial support for private housing discrimination in Northern cities while the celebrated School Segregation Cases of 1954 and $1955^{\circ}$ insisted that state and local governments in the South may not require racial separation in public education. On the constitutional question, the ruling in the first cases was that judicial enforcement of racial restrictions in deeds was not a private matter but actually amounted to "state action" which was forbidden by the Fourteenth Amendment. 
This reversed the generally accepted significance of the controversial case of Corrigan v. Buckley ${ }^{4}$ which since 1926 had given the courts of the District of Columbia and nineteen states strong justification for the enforcement of racial covenants. A different line of constitutional history preceded the more recent school cases. In the decisions there, the Supreme Court rejected flatly the rule of Plessy v. Ferguson, adopted in 1896, that "separate but equal" facilities satisfy the demands of the equal-protection clause.

The different origins of these two groups of cases tell a great deal about residential segregation in the North and school segregation in the South. Because of the federal problem, a case came up on both occasions from the District of Columbia. In addition, the Restrictive Covenant Cases arose under urban circumstances in St. Louis, Detroit, and Los Angeles. Various neighborhood property owners initiated actions to enforce restrictions against $\mathrm{Ne}$ groes. These owners were well organized at the local level but quite incapable of making a dent on national public opinion. Attorneys for the Caucasians were not known outside of their own cities and their defeat went practically unnoticed in the United States Congress. On the other hand, the most important of the School Segregation Cases, apart from the District of Columbia case, originated in the rural counties of Clarendon (South Carolina) and Prince Edward (Virginia). Two additional cases came to the Supreme Court from Claymont (Delaware) and Topeka (Kansas). Government attorneys in these places prepared the briefs and John W. Davis, an experienced and eminent advocate from New York, appeared before the Supreme Court in oral argument for racial separation in Southern schools. In contrast to the earlier covenant cases it was symbolic of general public interest and agitation that the attorneys general of Arkansas, Florida, North Carolina, Oklahoma, and Texas fled briefs amici curiae before the Supreme Court issued its 1955 decree in the school cases while the officials of other Southern states loudly protested that they would have nothing whatever to do with such displeasing, and hence unconstitutional, proceedings. Although we are often told that race relations in the North is also a problem, it is one which, for the moment at least, is regarded quietly in national politics. Meanwhile the controversy following the School Segregation 
Cases rages in party conventions, election campaigns, in Congress, and newspapers and magazines over the nation.

In the perspective of time, the significance of the Restrictive Covenant Cases may lie in what went into them rather than in what came out. There the National Association for the Advancement of Colored People made a full-fledged trial run in pressing for the expansion of Negro rights. This perfected the techniques the NAACP developed in twenty-five cases during the period from 1909, when the organization was formed, to 1947, when the Supreme Court agreed to hear the first four covenant cases. No earlier litigation was comparable in scope to the Association's task of working to eliminate the judicial enforcement of racial restrictions in housing. To overcome the legal precedent that stood against them, the NAACP relied on the constitutional theory of "state action" with the latest social and economic facts about discrimination in housing to win the day. A study of these efforts of the National Association for the Advancement of Colored People, made though it is with the knowledge of its role in later events, will inform us of the legal support for racial intolerance in the North and the basic methods employed to exterminate it. The fact that racial segregation in the residential areas of America's largest cities has not been altered to any substantial degree suggests the limited potency of court victories in some cases. Nevertheless the Restrictive Covenant Cases brought some material advantage to Negroes and meant even more as a symbol of power and a portent of the future.

I chose to study these cases for a number of reasons beyond their importance in the recent developments in race-relations law. My chief aim was to learn something of the role of interest groups in the judicial process, and perusal of the United States Reports showed that a record number of separate amici curiae briefs by organizations had been filed in these cases. This seemed enough to justify a fuller study. Another purpose was to investigate the interplay of historical forces in recent constitutional development. The rise and fall of court enforcement of racial covenants took place entirely in a period of four decades, a time of satisfactory length to consider economic, social, political, and intellectual developments and their impact on the law. Public policy on restrictive covenants had developed almost wholly 
within the judicial branch of government, and this limitation not only seemed likely to keep the study within manageable limits but also might balance a tendency in writings about the Supreme Court to overemphasize its power to review legislation.

Despite the reasons that led to my selection of the Restrictive Covenant Cases as a focus I have no doubt that the study of any number of other Supreme Court cases in diverse fields, and at different times, would reveal similar patterns of organizational activity. Even here the protective associations and real-estate boards were for many years successful in persuading state courts to enforce racial restrictions through injunction proceedings. It is the nature of the judicial process and the power that courts have in the American system of government which make organized groups care about adjudication. I hope in studying other court cases to refine an approach to the problem and to develop generalizations on the theme.

I wish to acknowledge the assistance I have received in preparing this volume. Many persons who worked for or against the c forcement of racial covenants have provided information by correspondence or by permitting access to legal and organization files. These include Gerald L. Seegers, Emil Koob, Herman Willer and Mrs. Margaret Bush Wilson of St. Louis; James Crooks and Dean George M. Johnson of Washington; Loren Miller of Los Angeles; Willis M. Graves of Detroit; and Charles Abrams, Joseph B. Robison, and Mrs. Constance Baker Motley of New York. I am also indebted to Robert L. Carter and Phineas Indritz who read and made suggestions on the manuscript. This book began as a doctoral dissertation at the University of Wisconsin, and I am indebted to David Fellman for advice and encouragement. Finally, a grant from the Faculty Research Fund Committee of Bowdoin College is acknowledged.

Permissions to quote correspondence and other unpublished materials were granted by Charles Abrams, Roger Baldwin, Robert L. Carter, James A. Crooks, Morris L. Ernst, Lewis Gannett, Phineas Indritz, Newman Levy, Loren Miller, Joseph B. Robison and Gerald L. Seegers. Permissions to quote copyrighted materials were granted by Charles Wallace Collins and Little, Brown and Company; the American Jewish Committee and the Jewish Publication Society of America; and Charles M. Storey and 
the Houghton Miffin Company. Permissions to quote from my own articles were granted by William W. Falsgraf, editor in chief of the Western Reserve Law Review; David Fellman, editor of the Midwest Journal of Political Science, and Harold A. Basilius, director of the Wayne State University Press. The epigraph to this book was taken from Philip Elman, ed., Of Law and Men: Papers and Addresses of Felix Frankfurter, 1939-1956 (New York: Harcourt, Brace, 1956).

A number of persons generously provided photographs of themselves. I also wish to thank the following for assistance in obtaining other illustrations: Mrs. Louis T. Wright for the photograph of Charles Houston; Mrs. Louis Wirth for the photograph of her husband; Dr. Davis McEntire for the maps prepared by the Commission on Race and Housing; P. L. Prattis, editor of The Pittsburgh Courier, for the reproduction of a front page of his newspaper and the photograph of George L. Vaughn; and Miss Barbara L. Clark of Harris \& Ewing for a number of photographs.

Brunswick, Maine

Clement E. Vose

\section{PREFACE TO THE SECOND PRINTING}

In the years since this book was written, the gap between the promise of the American creed and its fulfillment for Negroes has widened. This creed, expressed in noble 18th and 19th documents, was the measure adopted by Myrdal to judge the practical position of the Negro in his monumental book AN AMERICAN DILEMMA (New York, 1944). The creed has been enlarged since the restrictive covenant cases by the Supreme Court in decision after decision, by presidents in messages, orders, proclamations and speeches, and even by Congress in the Civil Rights Act of 1964 and other measures. Practice in the form of widespread opportunity for Negroes has improved, but its pace has clearly been too slow to bring social, economic and political accomplishment and power up to the expectations created by the new levels in legal status. The recent riotous destruction in Negro communities in northern cities is an expression of the sad difference between theory and practice in American race relations. 
Today my view of the restrictive covenant cases is that they were essential in wiping out what was in the first place a judiciallymade barrier to Negro access to housing. It exaggerates what the Supreme Court can do or thought it could do to think that its decision alone could end housing segregation in the United States. Yet I readily agree that the differences between legal and social change are more profound, and gaps between them more potentially explosive than I had once believed. My account of how the restrictive covenant cases originated and developed remains unchanged. Its thesis, that organized interest groups are often the significant moving spirits in constitutional cases, appears to have a durable meaning for social scientists. Many books and articles have since shown the various ways in which organizations participate in "test cases" concerning a wide range of legal issues. I think that the detail presented in this book shows that no very simple theory about constitutional litigation will be possible. Indeed, I endeavor to give readers enough information to draw their own conclusions about how the Supreme Court made these decisions.

Middletown, Connecticut

C.E.V. July, 1967 